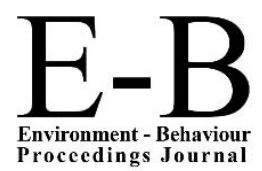

\title{
AicE-Bs2016Edinburgh
}

$7^{\text {th }}$ Asia-Pacific International Conference on Environment-Behaviour Studies, St Leonard Hall, Edinburgh University, United Kingdom, 27-30 July 2016

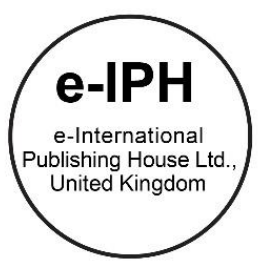

\section{Morphology of Traditional City Center in Semarang: Towards Adaptive re- use in urban heritage}

\author{
R. Siti Rukayah, Dhanang Respati Puguh, Endang Sri Susilo Setiyorini \\ Master Program of Architecture, Engineering Faculty, Universitas Diponegoro*, \\ Department of History, Culture Faculty, Universitas Diponegoro, \\ Marine Science Faculty, Universitas Diponegoro, Indonesia
}

\begin{abstract}
This study is a continuation of dissertation and studies after that. The concept of most of the traditional city in Java are waterfront city. Old Semarang traditional city center used to have to move four times. All of them laid along the river. Jurnatan (1695), The Gabahan (1659), Sekayu (1666) and Kanjengan (1670). But there is no explanation about the formerly of the city form to support the Program Planning and Preservation of Heritage Cities. How were the traditional city patterns at the time? How to conduct adaptive reuse to promoting the heritage cities in Indonesia to be recognized as World Heritage Cities by UNESCO? The serial maps from KITLV. NL, Tropenmuseum and Atlas Mutual Heritage will superimpose on an aerial view from google earth. Analysing using a sketch and computer aided design will peel the layering of the development of the city along the river. The result will compare with the Johannes $R$ hand drawing of Semarang in 16 s centuries. The formerly city form of Semarang in $16 s-$ 18 s centuries had a history as international port based on the maritime power at the time similar with Malaka. Malaka since 1984 become world Heritage site could become a best practice for next research to attract tourism.
\end{abstract}

(c) 2016. The Authors. Published for AMER ABRA by e-International Publishing House, Ltd., UK. This is an open access article under the CC BYNC-ND license (http://creativecommons.org/licenses/by-nc-nd/4.0/).

Peer-review under responsibility of AMER (Association of Malaysian Environment-Behaviour Researchers), ABRA (Association of Behavioural Researchers on Asians) and CE-Bs (Centre for Environment-Behaviour Studies), Faculty of Architecture, Planning \& Surveying, Universiti Teknologi MARA, Malaysia.

Keywords: Semarang, Alun-Alun, river, coastal, city center;

\section{Introduction}

\subsection{The Lost of Identity of Ex Semarang City Center as Riverfront City}

\footnotetext{
* Corresponding author. Tel.: +0-000-000-0000

E-mail address: tututrsiti@yahoo.com
}

2398-4287 @ 2016. The Authors. Published for AMER ABRA by e-International Publishing House, Ltd., UK. This is an open access article under the CC BY-NC-ND license (http://creativecommons.org/licenses/by-nc-nd/4.0/).

Peer-review under responsibility of AMER (Association of Malaysian Environment-Behaviour Researchers), ABRA (Association of Behavioural Researchers on Asians) and CE-Bs (Centre for Environment-Behaviour Studies), Faculty of Architecture, Planning \& Surveying, Universiti Teknologi MARA, Malaysia.

DOI: http://dx.doi.org/10.21834/e-bpj.v1i4.91 
City heritage has undergone many changes in its development. In fact, sometimes the younger generation has forgotten the history of the city. Adaptive reuse refers to the process of reusing an old city area or building for a new purpose other than which it was built or designed for. Adaptive reuse deals with the issues of conservation, preservation, and heritage city policies.

Heritage cities have now become a trending topic and getting attention because Indonesia's economic growth is very rapid and is feared to erode heritage traditional character. City heritage is a noble heritage of Indonesia. Maintenance of Heritage Cities is listed in Act No. 28 of 2002 on Building. In Article 38, paragraph 1 mentions the building of buildings and surroundings that are designated as cultural heritage in accordance with the legislation must be protected and preserved.

In order to encourage the structuring and preservation of Heritage Cities, in December 2012, the government established the Conservation Charter Indonesian Heritage Cities. Even the Ministry of Public Works seeks to promote the establishment of heritage cities in Indonesia to be recognized as World Heritage Cities (World Heritage City) by UNESCO.

Bulletin Ciptakarya, 2015 stated that Central Java Province by the Ministry of Public Works will implement the Programme Planning and Preservation of Heritage Cities. In the initial phase, 10 cities/countries will be a pilot project, the city of Banda Aceh, Sawahlunto, Palembang, Bogor City, Semarang, Yogyakarta, Banjarmasin, Baubau City, Denpasar, and Karangasem.

Semarang has many heritage areas but has not maintained yet. As a city port in the 7th century recorded in the news of travel foreign sailors, the Chinese news by the Mahuan. An ancient sketch/ painting by Johannes $\mathrm{R}$ in the 16th century described the natives Semarang city center right at the river bank. Semarang had four times of the movement native city center and all of them laid along Semarang river. Rukayah, Hartuti, 2013 stated that old native city center was Jurnatan (depicted on old map Semarang 1695), the Gabahan (1659), Sekayu (1666) and Kanjengan (1670). The city center Semarang have similarity with Islamic sultanate city at northern Java. The component of Islamic sultanate city according to Andrisijanti, 2000; Tjandrasasmita, 2000, consisted of traditional square (Alon-Alon), the palace, mosque and market. The king and his palace as the center of the city (Wiryomartono 1995; Geldern 1972). Rukayah, 2007 added that the concept of the traditional city is waterfront city.

Only Sekayu and Kanjengan city center that still could be traced as a traditional city. How was the initial form of ex-downtown indigenous administration? Even their still existence but tend to undergo continuous degradation as waterfront city and as the traditional city center. How are the strategies to conserve them?

\subsection{Research Problems}

Many researchers have studied the river but more inclined to research the physical aspects of the river itself (Anan, 2011). There are many researchers who studied architecture and urban aspects. This study explored the architecture and urban design based on heritage from the four of Traditional Semarang city center along the river that made by indigenous communities and now lost their identity due to modernization.

\subsection{Goal}

The purpose of this study is to find an early form of old Semarang city center in Sekayu and Kanjengan. Basic maps, spatial patterns and the presence of the building in the early establishment of the city center are the basis of the concept of conservation efforts in the region waterfront city for nomination as world heritage city. The findings could Also enrichment course for students majoring in architecture.

\subsection{Outcome Research}

The founding of concept is a new concept of traditional urban design along the river Semarang. This finding could be the starting material to conduct further research in order to propose Semarang as a world heritage as Malacca. 


\subsection{Limitation To Study}

Old Semarang in the 16th century was not documented. Map available from Atlas kitlv.nl and mutual heritage from the late 17th century with the image detail in areas of the Dutch colonial fort, Image of four native cities received less attention. Only old Kanjengan that got the attention. To get data on old Sekayu, by comparing of a variety of old maps will get an estimate of the condition of the region in the first era.

\section{Literature Study}

\subsection{Preliminary Literature Study and Road Map of This Research.}

These are the serial research as preliminary study. In 2007, researchers revealed that the concept of a waterfront city from the empire/ sultanate cities as traditional city center along the northern coast of Java. Dissertation research in 2010 found the Sustainable of traditional City Center in Java. In Semarang city center, central Java, Rukayah, Hartuti, 2013 has reconstructed the shape of Sekayu area as old Semarang city center. Rukayah, Bharata, 2012, also have reconstructed the Kanjengan as old Semarang city center (2012). However there is limited data at that time and data of old map has not launched free by the Dutch government. Now with the free access to get data from multiple webs on the internet, the research on to uncover of old morphology Semarang especially in Sekayu and Kanjengan and how the correlation both of them will be clearer.

This study is the first stage of a whole series of research to find the concept of the waterfront city. The second stage is to map the unique of architecture and find the sense of place of four ex-old Semarang traditional city center along the river. Research phase three is the conservation to restore the glory Semarang river as a port town in the era from the perspective of architecture and urban design and making it feasible to propose Semarang as world heritage.

\subsection{Theoretical Review}

\subsubsection{Morphology}

Topcu, 2012, stated that urban morphology can be defined as an approach that provides an understanding of the form, creation and transformation processes, spatial structure and character of human settlements through an analysis of historical development processes and the constituent parts that compose the settlements.

There are several approaches in the search for a morphological pattern of the city, both historical and modern. According to Conzen in Birkhamshaw, Alex $\mathrm{J}$ and Whitehand (2012), the morphology of the city has three components: ground plan, building form and utility of land / building. Zahnd, 1999. perform group analysis figure/ground, linkage and place. It can be concluded that morphology approach is a process associated with the formation of the city's history. The process of development can be formed structural, functional and visual.

\subsubsection{Adaptive reuse}

What is adaptive reuse?According to the Commonwealth available from the Department of the Environment and Heritage, 2004, Adaptive reuse is a process that changes a disused or ineffective item into a new item that can be used for a different purpose. Sometimes, nothing changes but the item's use.

Addo, 2010 in study for adaptive reuse of old buildings in Old Accra world heritage site suggested that in recent times it is not only an old building that should be put to a new use but also where possible an old and a new building can be merged making it possible for old buildings and new buildings to be fused in design to perform as one unit. 
According to Adaptive reuse; Preserving our past, building our future (2004) the benefits of adaptive reuse are more significant for the environment, social, economy and tourism and also will be contributing to the livability and sustainability of their communities. Although adaptive reuse has many benefits it faces a number of limitations, ranging from planning laws and building codes to ownership and use of the buildings.

\subsubsection{Toponym And Structural Patterns of old Java City Center}

According to Karsidi. 2013, experts of geography, toponyms or geographical names is a tool to learn the cultural and historical aspects. In studying the history of the ancient city in Java, anthropology expert, Inajati 2008, managed to uncover the pattern structure of the city by the remains of toponyms. He claimed there was a similar pattern in each of the traditional city center in Java in the Islamic Mataram era depicting various professions, origin, character names, jobs in addition to their physical artifacts such as palace, Alun-Alun, mosques, and others. The division of the area in such a city on Java is not known in pre-Islamic times.

The Placement of old city center followed the North- South axis. (Santoso, 2008, Inajati 2000, Rukayah 2010). Rukayah, 2007, stated that the axis formed of the Java Sea in the northern Java as transportation of world trade at that time. Layout and pattern of traditional town and toponym heritage become a tool for tracing the old city in Java that lost their shape and identity.

\subsection{Conservation of City Heritage in Indonesia: Malaka dan Kyoto as best practice}

According to Cohen, 1999, Gill, 1994, conservation of the city include the architectural and historical character of the town. Unfortunately, the implementation of conservation in Indonesia based on the Law of the Republic of Indonesia Number 5 of 1992 only stipulates the preservation and utilization of cultural heritage objects, not including the heritage area. Likewise Charter Indonesia Heritage Year 2003 includes the preservation of natural heritage, cultural heritage, and the heritage of nature and culture. With the same problem, heritage conservation in Indonesia is still not as detailed as what has been done by the Malacca and Kyoto.

In the book Present Town and Landscape Preservation in Kyoto, 1997, urban conservation in Kyoto include the preservation of historic townscapes, urban landscape preservation, preservation of green space, preservation of scenic, landscape and preservation of the natural landscape. Field trip to Kyoto in 2014, this city attracts tourists because of its ability to conserve the ancient city area. Meanwhile, Malacca has a fascination for Chinese travelers because of efforts to preserve the heritage associated with China such as Baba Nyonya heritage and Princess Hanglipoh emphasis on the history of Chinese origin. (Norlizaiha and Ismail, 2011, Moya, Phongpanichanan, 2014). Field trip to Malacca in 2013, 2014, this historic district has a river tour package with artifacts concept of waterfront along the Malacca River.

Linking tourism with heritage and culture will be a benefit to the local community and the local economy (Lussetyowati, 2015). In some areas in Indonesia conservation of historic cities along the river in Surabaya, Palembang has gained the attention of the government. This activity could be a stimulus for other cities in Indonesia.

\subsection{Waterfront city}

This concept originated in the 1970s when towns ports in America have become slums alarming process. The success example of Baltimore's Inner Harbor project, urban waterfront revitalization has been steadily extending in many cities worldwide. In Europe, since the 80s, numerous examples on different scales have been produced the potential of historic revitalized waterfronts to become urban creative hubs and creative tourism attractions. (Kostopoulou, 2013). This concept spread to many countries and examples of waterfront revitalization strategy in this small town may be appropriate as best practice. According to Good JW and Goodwin RW. 1990, there are several stages in performing waterfront strategies for small towns. Stage 1. Planning and getting the community involved and involving state and federal agency 2. Surveying and mapping the most urgent problem Stage 3. 
Developing the waterfront plan and making cost estimates. Stage 4. Implementing, managing and marketing the waterfront plan for the promotion of tourism.

There are several obstacles in the implementation of adaptive reuse in urban design, namely the public policy and the owner of several buildings. Morphological study to uncover the shape, structure, and formation of a place. Kyoto and Malacca became a best practice policy regarding conservation and waterfront revitalization strategies that attract tourism.

\section{Methodology}

Based on the research questions what were the formerly city shape in Semarang especially in Sekayu and Kanjengan, so the historical method and naturalistic are the best way to find the answer. The mixing method will use because to unrevealed the phenomenon in the past and continued by conduct study in recent time. To conduct a historical study of Semarang city in the past, the data is sourced from Kitlv.NL, Tropenmuseum and atlas mutual heritage are very important. Semarang city as a city that was once occupied by the Dutch in the colonial era $16-18 \mathrm{~m}$ century has a lot of maps, photos, and ancient pictures are stored as archives in Netherlands. Map and picture will be used to reveal the layering of the historical development of the city.

Old maps superimposed on google map layers 2016 serve to show the form of the city. Old maps obtained from Atlas Mutual Heritage in 1695 and 1741. Next Serial maps obtained from Tropen Museum and kitlv.nl 1875, $1180.1888,1892,1909.1917$ and 1945. The limitation of this method was the lack of information about old Sekayu.

To covering the lack of data of old Sekayu, doing naturalistic method will present the recent condition to support the old data. The naturalistic method will conduct without carrying any theory. New knowledge will be extracted from the data in the field. Deep interview with the headman, the manager of the mosque as local people/ key person can help to reveal of the historical aspect. The last step is to make Hand drawing/ sketch, to make the artist image I impression for re-imagining Semarang in the past.

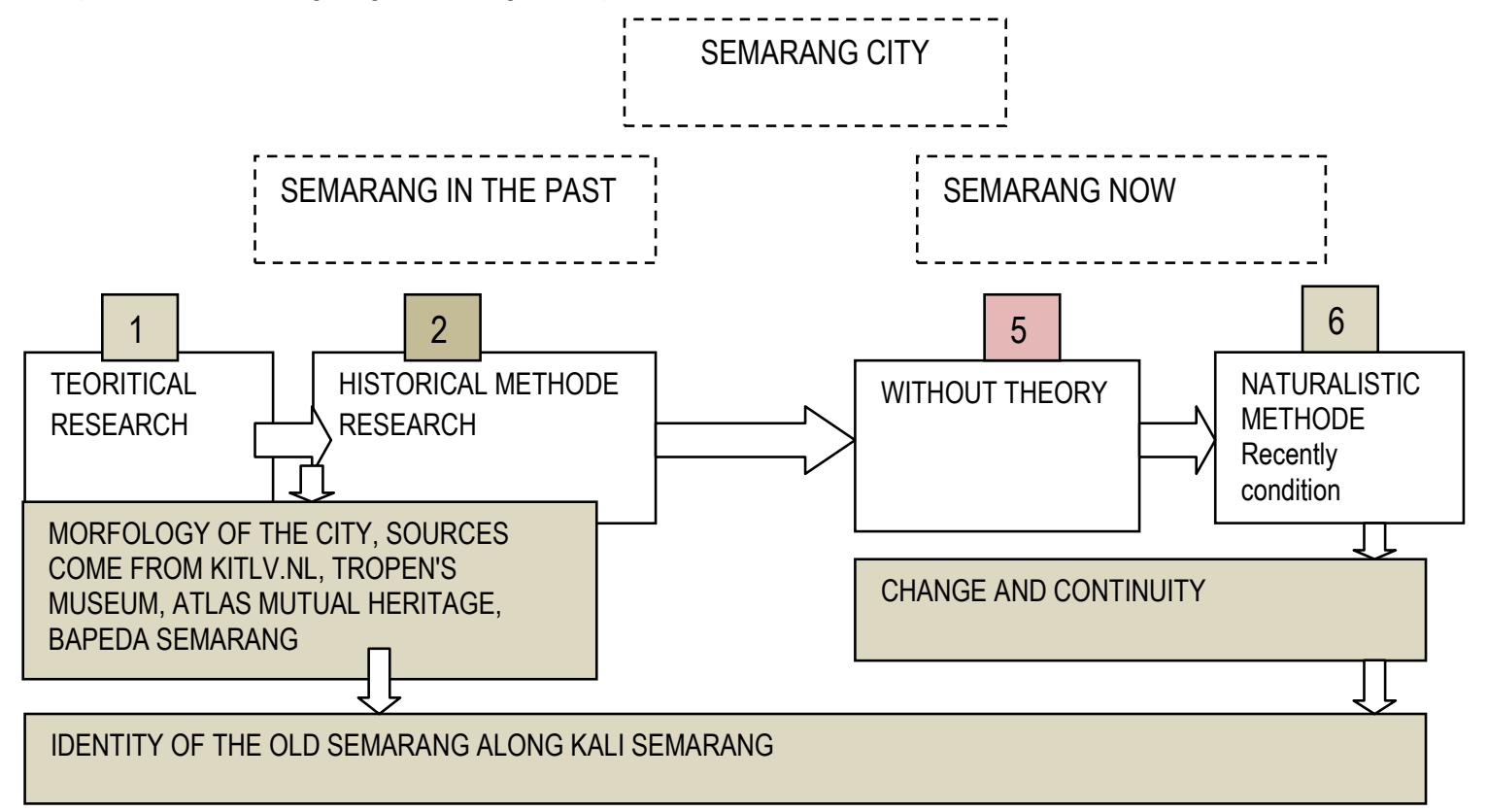

Fig. 1. Mix methode, Sources : analysis researchers 2015 


\section{Continuous Degradation of Ex-City Center in Sekayu and Kanjengan.}

Similar to Malacca district, Semarang city at that time also a port city and recorded in travel news, foreign seafarers. The old town in Java at the time are that Phalimbham in Banten Province and Lu Singe in Bengkulu. Chalava (Sunda Kalapa), Pragota. Some sailors even skilled in sketching / drawing state port cities (Valentyn, Lodewick, Odorico, Johannes $\mathrm{R}$, etc.).

Functions as a port city and a place to settle for the sailors from various nations, inspired Ki Ageng Pandanaran in the 16th century moved downtown from The Bogota to Bubakan/ Jurnatan. City bustling city atmosphere and the presence of multi-ethnic settlements (villages now Army -see map) be the choice as the new city center. in the era of the next government, at every turn of the head of government, followed by the migration of the downtown location. Bubakan. The Gabahan 1659, Sekayu 1666 and Kanjengan in 1670.

Now all the four of the city centers have lost the characteristics (Rukayah, Hartuti, 2013) found that in front of Sekayu Mosque formerly is open space. Which is just the Alun-Alun or only the open space?

The location of Kanjengan and Sekayu in line with Pemuda street, the part of the great mail road. This corridor has developed into a trading and services since the Dutch colonial era and gained the culmination in the 1970s. At that time, the mayor of Semarang made authority project by involving the private sector to developE the city of Semarang. Municipalities provide the location for the construction. Kanjengan was the first location as an experiment. Some shops, hotels, theaters, Fruit Market-Yak Permai (the location os market covered the open space of Alun-Alun) and Kanjengan shopping center replaced The Regent office of Kanjengan. The development of old Kanengan area began to transform the downtown area from traditional to commercial space, Rukayah, 2010. Previously, the colonial government in 1809-1811 has split the old square with a great main road that connects the cities of the north coast of Java. In 1930, the Dutch colonial built Johar market on the East side of the square blocking the square view directly to the river. The concept of waterfront city disappeared. Now only the mosque and village Kauman remaining as a reminder that the area was a traditional town center.

In Sekayu, the remnants of the city center in the past are the oldest mosque in Semarang. Kampung and mosque in the past were a place for gathering wood for the construction of the Great Mosque in Demak. According to Dewi and Evansah, 2014, now one of the areas in Kampung Sekayu have lost due to the construction of Paragon mall (2010). Kali Semarang has a history as the connecting line for four native city center, multi-ethnic villages such as Melayu, Jawa, Tionghua dan Eropa. Now Semarang river has lost the existence since the road great mail road the 18.

\section{Analysis}

Based on the survey in all ex-city center in Semarang in 2016 only Sekayu and Kanjengan that still shows remnants of the architecture of the building as a pointer that the location has been no central government (Rukayah, Hartuti 2013). Jurnatan area is already covered by a shopping center Plaza Semarang. Only a toponym Jurnatan could refer that in the region used to be the former administrative center. Jurnatan means the head of the administrative city. The Gabahan area now covered by the settlement.there are the toponym Sebandaran which refers that the area was once a port.

Based on the old map Sekayu and Kanjengan and by tracing the current condition, the shape and structure old indigenous administration in the past were a waterfront city. It is estimated that in the past the city is still relatively walkable and accessible and connected by river channels. There are allegations that the concept of the old city pattern opposite to the city center and the indigenous city center in Jurnatan and the Gabahan. Because both of them located on the East side of the river. 


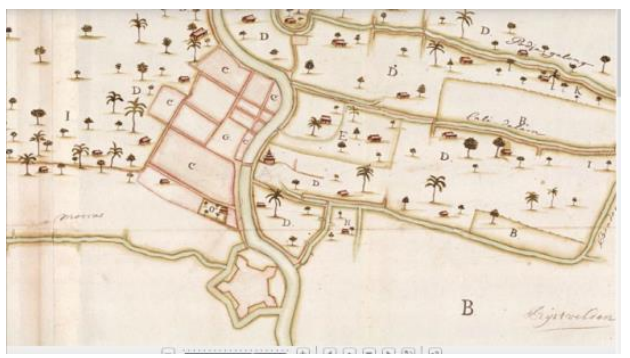

On a map situation of the city of Semarang years 1695 , there was a mosque on the west side of the river it is estimated that location was the Kanjengan now. Chinese town on the south side, fortress dutch colonial, Javanese kampong, native government office and market in china town. Sources : atlas mutual heritage

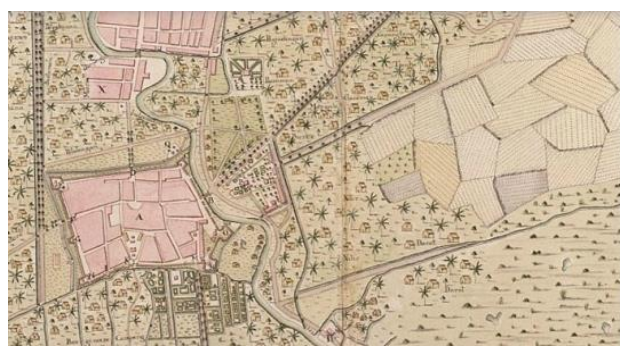

On a map, 1787 the Pecinan has been on site now. The located of the colonial city as same as the recent position. The old Kanjengan, Islamic settlement, mosque, native government office, the square clearly depicted on this map. Sources: atlas mutual heritage

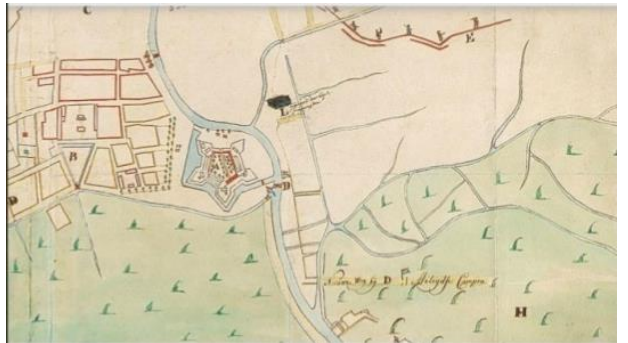

Based on a map years 1741 , the old city center Kanjengan having marks the large of a banyan tree. Located on the west side of the citadel colonial. Melayu settlement on the north side . Source: atlas mutual heritage

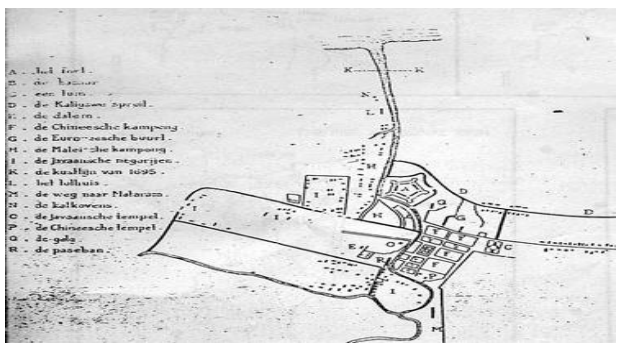

The embryo of old Semarang has shown on a simple sketch of Semarang city in 1719 .Sources: Dinas PU Cipta Karya, 1993/1994

Fig. 2 .Tracing the morphology of old Semarang in Kanjengan, Resources: Atlas Mutual Heritage

\subsection{All The Old City Center Of Semarang Laid Along Semarang River.}

Based on the Sekayu serial ancient map, it is possible that in front of the mosque was once an open space directly facing to the river. Researchers suspect that Johannes Racht painting about the old city Semarang in the 16th century was Sekayu with mosque and villas in great mail road as background. It was similar with old Kanjengan, the square facing directly to the river Semarang. 


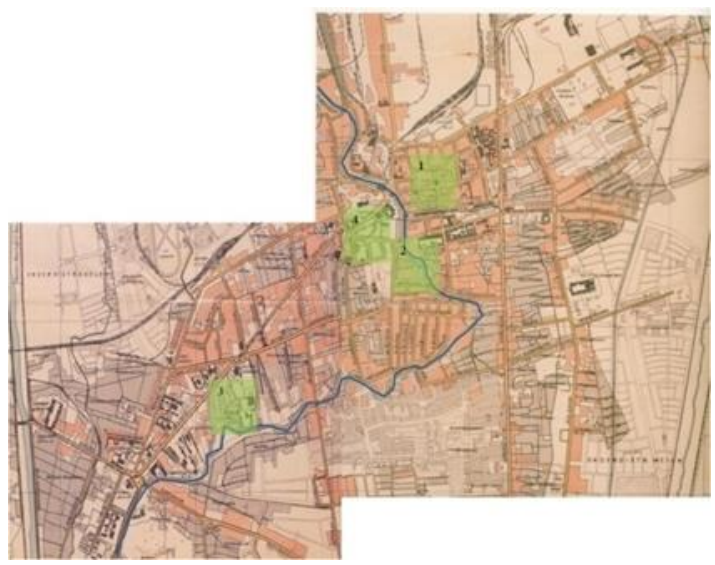

Fig. 3 . The location of four old eks Semarang city center along the river Semarang. Sources: Brommer and analysis researchers 2015

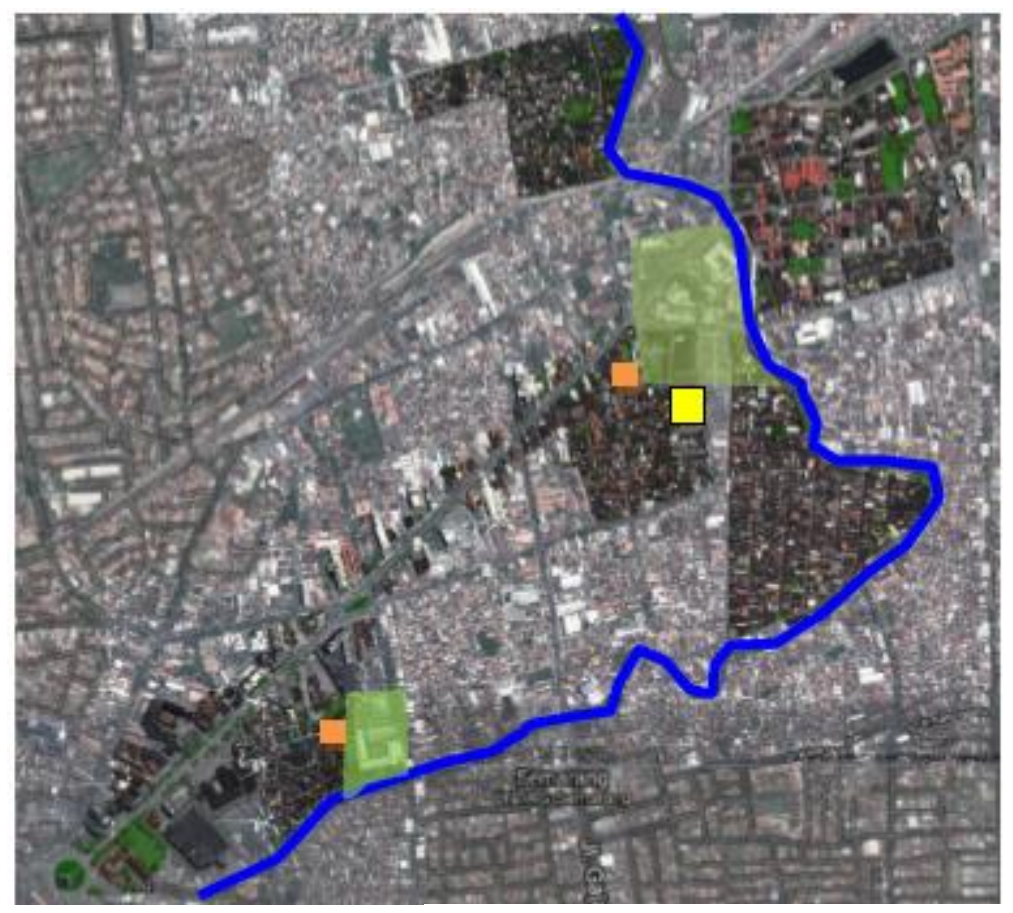

The mosque and the possibility of the location of alun-alun Sekayu, facing the river at the time

Fig. 4 . River front city concept of old eks Semarang city center g. Sources : analysis reserachers 2015

\subsection{Semarang River, Connecting Space History}

The region around the mouth of the river Semarang then is a traffic shipping small boats with many routes of traders who come from outside the Semarang (Budiman, 1978). The development of old Semarang of 1719, 1800, 1875, $1880,1888,1892,1909,1917$ and 1945 revealed the growth of the capital city along Semarang river.Recorded in 
simple- sketch map 1719 is the port, native government office, traditional square (Alun-Alun), China town, Dutch Colonial settlement, Melayu village, Javanese village, mosque, Chinese temple etc .

The cultural heritage area along the river including old city center Semarang and ethnic Semarang settlement is a space continued history unveiling the development of cities Semarang from the beginning of its formation

\subsection{Redevelopment Plans: Great mail Shopping Street and River cruise tourism}

Based on the background and the potential, Semarang is one of the large inheritance cultures in Indonesia. But on the other hand, there are a number of threats and the destruction on the exterior it is the city center Semarang as the area inheritance culture.

Similarly, the various study on old Semarang, particularly those relating to its status as the cultural heritage still focus on works colonial city and have not touched in the native city, the work of indigenous inheritance. Between old city center in Sekayu and Kanjengan, there is linkage structural with rivers as the main transportation line. The great main road connecting two areas old city center was either structurally and visually. Visual linkage not only connecting both cities indigenous but also to the fortified cities were located in east side Kanjengan area. The traditional Market laid on a part of Alun-Alun triggering commercial property around it. A relics of colonial architecture along this road have the potential to make image corridor as a commercial area.

The Semarang river can be having a resemblance to Malacca physically (the wide of the river, the character of architecture along the river and especially the history) and historical roots as a city port and the concept as a waterfront city. The riverside was filled with various culture diverse and charm building architecture of different ethnicities and nation that ever transmitted or continuing to settle there. The uniqueness of Semarang along the river is a continuous space history of the growth of indigenous central government.

However, the communities along the river don't have planned, financial, technical capabilities needed to mount a successful waterfront revitalization effort. In this sense, this guide will be a valuable resource for them. The city government plays the important role in many smaller communities.One revitalization and techniques is the land use control and incentives, the acquisition land important, choosing and using consultant to conservation times Semarang and the power as corridor heritage remember cities in Europe, Asia and Asia southeastern has developed it as tourism heritage by the river some order heritage in how the state that to is conserve be area shopping tourism exclusive.

The development of heritage property raises many valuation issues in the waterfront. The creation of a World Heritage site potentially raises much more. Current valuation techniques tend to be site specific and to be based on short property life cycles.

\section{Acknowledgements}

We would like to acknowledge the support from International Publication Research, Universitas Diponegoro for the financial assistance in the setting up of the research project.

\section{References}

Adrisijanti, Inajati. 2000. Arkeologi Perkotaan Mataram Islam. Jendela. Yogyakarta.

Broomer. (1995). Semarang Beld van Een Stad, Asia Mayor

Bulletin Ciptakarya, Edisi 06/Tahun XIII/Juni 2015

Cohen. Nahoum, 1999. Urban Conservation, The MIT Press, Cambridge, Massachusetts. 
Rukayah, Hartuti, 2013. Islamic City Structure In Sekayu Semarang (The Viewpoint Of Urban Design) Journal of Architecture, Planning and Construction . journals.iium.edu.my/kaedjournal Vol 3 no1/2013

Rukayah. (2005). Satu Lagi Potensi Wisata Sejarah, Temuan Typologi Konsep Alun-alun di Jawa, Kreasi Muslim Cina Anak Buah Cheng Ho. Pemenang ke 3 Lomba Penulisan Tingkat Nasional Cheng Ho dan Kaitannnya dengan Indonesia. dalam rangka peringatan 600 tahun pendaratan Cheng Ho.

Rukayah. 2010. Simbiosis di Ruang Terbuka Kota Simpang Lima Semarang. Disertasi Doktor. Program Doktor Teknik Arsitektur dan Perkotaan Universitas Diponegoro. Tidak dpublikasikan.

Rukayah, R. Siti, Bharoto, Abdul Malik. 2013. Conservation Concept on Areas with Overlapping Character .ajE-Bs Asian Journal of EnvironmentBehaviour Studies Volume 4, Number 13, May / June 2013 ISSN: 1394-0384.

Rukayah, Tomohiko Yoshida, Wijayanti, 2014.Public Policy to conserve space and Place at Cosmic City as World Heritage Tourism (Kyoto as best Practices in Yogyakarta and the other traditional Cities in Java, Indonesia), grant from Sumitomo Foundation, have not publicated yet.

Santoso 2008.Arsitektur-kota Jawa, Kosmos, Kultur \& Kuasa.Centropolis. Magister Teknik Perencanaan Universitas Tarumanegara.

Tjandrasasmita, U. 2000. Pertumbuhan dan Perkembangan Kota-kota Muslim di Indonesia dari Abad XII sampai XVIII Masehi.Kudus: Penerbit Menara Kudus

Wiryomartono. Bagoes P. A. (1995). Seni Bangunan dan Seni Binakota di Indonesia: Kajian Mengenai Konsep, Struktur, dan Elemen Fisik Kota sejak Peradaban Hindu-Budha, Islam hingga Sekarang. Jakarta: Gramedia.

Anan Gusti. 2011. Sungai-Sungai Di Sumatera Dalam Catatan Perjalanan Dan Laporan Penelitian Pada Masa Kolonial. Kementerian Kebudayaan dan Pariwisata Konferensi Nasional Sejarah IX.

The Case Study Of Kalimas River, Surabaya-Indonesia. Procedia - Social and Behavioral Sciences 135 ( 2014 ) 136 - 141.

Lussetyowati. 2015. Preservation and Conservation through Cultural Heritage Tourism. Case Study: Musi Riverside Palembang. Procedia Social and Behavioral Sciences 184 ( 2015 ) 401 - 406.

Moya Lisa Yong Yeu, Charuwan Phongpanichanan, 2014. Does the status of a UNESCO World Heritage City make a destination more attractive to Mainland Chinese tourists? A preliminary study of Melaka. Procedia - Social and Behavioral Sciences 144 ( 2014 ) 280 - 289.

Norlizaiha Siti Harun and Izzamir Ismail. 2011. The Conservation Plan For World Heritage Site: George Town, Penang, And Malacca, Malaysia. The 1st International Conference On Rebuilding Place: From Culture To Art And Architecture, University Kuala Syah, Banda Acheh, Indonesia, 4 October4, 2011/

Addo Natalyn Oye.2010, Harnessing Potential In Heritage Sites The Adaptive Reuse Of Old Buildings In Old Accra . Thesis Department of Architecture, Kwame Nkrumah University of Science and Technology Faculty of Architecture and Building Technology, College of Architecture and Planning November 2010

2004. Adaptive Reuse. Designed by Fivefold Creative Printed by the Pirion. The Commonwealth available from the Department of the Environment and Heritage. Commonwealth of Australia 2004 ISBN 0642550301

Zahnd, Markus .(1999). Perancangan Kota Secara Terpadu. Yogyakarta: Kanisius

Birkhamshaw, Alex J and J.W.R. Whitehand (2012). Convenient Urban Morphology and the Character Area of Planners And Residents. Urban Design International .

M.Greene, Mehmet TOPÇU. 2012. Old And New City: Morphological Analysis Of Antakya. Proceedings: Eighth International Space Syntax Symposium Edited by J.Reyes and A. Castro. Santiago de Chile: PUC, 2012. 8251:1

Good JW and Goodwin RW. 1990, Waterfront revitalization for small cities. Oregon State University.

Kostopoulou, Stella. 2013. On the Revitalized Waterfront: Creative Milieu for Creative Tourism. Sustainability. ISSN 2071-1050.

www.mdpi.com/journal/sustainability. 